\title{
Role of microparticles derived from monocytes, endothelial cells and platelets in the exacerbation of COPD
}

This article was published in the following Dove Press journal: International Journal of COPD

\author{
Margit Tőkés-Füzesi' \\ István Ruzsics ${ }^{2}$ \\ Orsolya Rideg ${ }^{3}$ \\ Péter Kustán' \\ Gábor L Kovács 1,4 \\ Tihamér Molnár ${ }^{5}$ \\ 'Department of Laboratory Medicine, \\ University of Pécs, Medical School, \\ Pécs, Hungary; ${ }^{2}$ Ist Department \\ of Internal Medicine, Division of \\ Pulmonology, University of Pécs, \\ Medical School, Pécs, Hungary; \\ ${ }^{3}$ Department of Pharmacy, University \\ of Pécs, Pécs, Hungary; ${ }^{4}$ Szentágothai \\ Research Centre, Pécs, Hungary; \\ ${ }^{5}$ Department of Anesthesiology and \\ Intensive Therapy, University of Pécs, \\ Medical School, Pécs, Hungary
} evaluated in COPD. in stable and exacerbated COPD patients. $0.5-1.0 \mu \mathrm{m}$.
Background: Microparticles (MPs) are shedding membrane vesicles released from activated blood and endothelial cells under inflammatory conditions. The role of endothelial MPs (EMPs) in pathophysiology of COPD is relatively well known. However, the release and function of MPs of other cellular origins, eg, platelets, red blood cells and leukocytes, are not clearly

Purpose: The aim of this study was to measure EMPs and other cell-derived circulating MPs

Patients and methods: A total of 50 patients with COPD and 19 healthy volunteers were enrolled in the study. EMPs (CD31+, CD62E+) and platelet-derived (CD61+, CD41+, CD42a+, PAC1+), red blood cell-derived (GlyA+) and leukocyte-derived (CD45+, CD13+, CD14+, CD56+) MPs were measured. Flow cytometry (FC) was performed on Beckman Coulter FC500 analyzer. MP reference gate was set using $0.3-0.5-0.9 \mu \mathrm{m}$ microbeads with MP size gates of

Results: All the measured MPs were significantly $(P<0.001)$ higher in COPD patients than in the controls. Furthermore, CD62E+, CD41+, CD42a+ and CD14+ MP values were significantly $(P<0.001)$ increased in exacerbated COPD compared to stable COPD. These MPs showed significant $(P<0.001)$ inverse correlation with $\mathrm{FEV}_{1} / \mathrm{FVC}$, as well.

Conclusion: In this study, we describe a reliable flow cytometric assay for MP analysis that was successfully applied in COPD. Besides EMPs, COPD is accompanied by an increased concentration of various MPs in the systemic circulation; particularly, platelet- and monocytederived MPs seem to be important in exacerbation.

Keywords: cell-derived microparticles, biomarker, COPD, flow cytometry

\section{Introduction}

Microparticles (MPs) are defined as small $(0.1-1.0 \mu \mathrm{m})$ lipid bilayer-limited microvesicular bodies with variable exposure of phosphatidylserine in their outer membrane leaflet. The membrane skeleton may be present, but the nucleus is absent and the bodies lack synthetic capacity. They are involved in intercellular communication, signal transduction and mediated receptor, virus and prion transfer. MPs are also known to take part in protein and mRNA/microRNA transport, waste management, coagulation, angiogenesis, inflammation and cell activation. ${ }^{1-3}$ MPs are released into the extracellular microenvironment during apoptosis, cell activation or exposure to shear stress in physiological or pathological conditions as inflammatory disorders. ${ }^{4}$ Nowadays, the quantity and the cellular origin of MPs are widely studied. Their cellular origin could be distinguished based on their surface protein's characteristics
Correspondence: Tihamér Molnár Intensive Therapy, University of Pécs, Ifjúság u I 3, 7624 Pécs, Hungary

Tel +36 72535832 ext 32420

Fax +36 72503681

Email tihamermolnar@yahoo.com
International Journal of COPD 2018:13 3749-3757

3749

Dovepress in

http://dx.doi.org/10.2147/COPD.S175607 (c) (1) (5) 2018 Tökés-Füzesi et al. This work is published and licensed by Dove Medical Press Limited. The full terms of this license are available at https://www.dovepress.com/terms.php cc) hereby accept the Terms. Non-commercial uses of the work are permitted without any further permission from Dove Medical Press Limited, provided the work is properly attributed. For permission for commercial use of this work, please see paragraphs 4.2 and 5 of our Terms (https://www.dovepress.com/terms.php). 
as CD markers. The most relevant host cells are endothelial cells, platelets, red blood cells and leukocytes (neutrophils, monocytes, lymphocytes). ${ }^{5}$

Accumulating evidence suggests that cell injury in lung tissue is closely connected to disease progression in COPD. Due to the endothelial injury in the pulmonary capillary vasculature, endothelial MPs (EMPs) are now receiving attention as potential biomarkers for COPD. They might predict the presence, progression and degree of endothelial damage in COPD patients. ${ }^{6}$ The release of MPs from other cellular origins, eg, platelets, red blood cells and leukocytes, is not clearly understood in COPD. However, these cells are also activated during COPD pathophysiology, and COPD is also associated with several comorbidities and linked to systemic inflammation. ${ }^{7,8}$ Therefore, the role of MPs of various origins would be of great interest in understanding both the course of COPD and its effect on remote organ failure.

To detect and analyze MPs, different methods have been described, but due to technical variety and several difficulties, conflicting data have been reported. ${ }^{13-17}$ Nowadays, flow cytometry (FC) is the most frequently applied method in MP analysis, although there is no standard protocol for isolating and detecting circulating MPs from the plasma.

The aim of this study was to measure various MPs from different cellular origins in COPD patients with a reliable flow cytometric method for diagnostic purposes.

\section{Patients and methods}

\section{Patients}

The study protocol was approved by the Regional Research Ethical Committee, University of Pécs (3429/2009). Written informed consent was obtained from each patient and healthy subjects.

A total of 50 patients with COPD, who were treated at the 1st Department of Internal Medicine, Division of Pulmonology, University of Pécs, were recruited into this prospective clinical study. The diagnostic criteria and the GOLD stratification for COPD patients were made according to GOLD. ${ }^{9}$ Exclusion criteria in COPD patients were major factors that could significantly alter MP amounts such as hematological diseases, kidney diseases, cytostatic treatment in the past 30 days, patients with disseminated intravascular coagulation score of $\geq 5$ and antiphospholipid syndrome. ${ }^{10}$ Besides, clinical factors (including smoking habits, comorbidities and medication) of patients, which could alter MP values, were recorded. Definition of exacerbated patient is as follows: hospital admission and intravenous corticosteroid therapy were urgently initiated based on the worsening of the symptoms such as increased sputum, cough and signs of respiratory distress. COPD patients presenting for regular yearly checkup and without novel symptoms were considered as stable.

The data were compared to an age-matched control group consisting of 19 volunteers. The healthy state was assessed based on medical records, physical examination and laboratory data. The exclusion criteria were the same as in the COPD patient group.

\section{Blood sampling}

Anticoagulated, fasting venous blood samples were drawn with $21 \mathrm{G}$ needles after short strangulation from the antecubital vein into $2.7 \mathrm{~mL} 3.8 \%(0.129 \mathrm{M}) \mathrm{Na}_{3}$ citrate containing closed blood collection system tubes (BD, Franklin Lakes, NJ, USA). Upon blood collection, the first $3 \mathrm{~mL}$ blood was collected in a separate vial and discarded. The blood samples for MP measurements were transported immediately to the laboratory and processed within 1 hour.

\section{MP isolation and flow cytometric measurements}

Currently, there is no standardized method for MP analysis. Because of this, and to avoid false-positive MP results, we developed a method for MP isolation as follows.

Blood was centrifuged at $800 \times g$ for 20 minutes at room temperature to obtain platelet-rich plasma. Then, $1.5 \mathrm{~mL}$ supernatant was transferred into a new test tube and centrifuged at $1,500 \times g$ for further 20 minutes to obtain platelet-poor plasma (PPP). Afterward, $1 \mathrm{~mL}$ PPP was further centrifuged at $1,500 \times g$ for 20 minutes in a new polystyrene tube to obtain cell-free plasma. The top $500 \mu \mathrm{L}$ of cell-free plasma was transferred into an Eppendorf tube and pelleted at 18,000 $\times \mathrm{g}$ for 10 minutes. The supernatant was carefully removed leaving $25 \mu \mathrm{L}$ of MP-rich plasma at the bottom of the Eppendorf tube. MPs were suspended with gentle vortexing for 20 seconds in $1.0 \mathrm{~mL}$ Apo-binding buffer $(10 \mathrm{mmol} / \mathrm{L}$ HEPES-4-(2hydroxyethyl)-1-piperazineethanesulfonic acid [Sigma-Aldrich Co., St Louis, MO, USA], $5 \mathrm{mmol} / \mathrm{L} \mathrm{KCl,} 1 \mathrm{mmol} / \mathrm{L}$ $\mathrm{MgCl}_{2}, 136 \mathrm{mmol} / \mathrm{L} \mathrm{NaCl}, \mathrm{pH}=7.4$ ) without $\mathrm{CaCl}_{2}$.

In this study, only Annexin V+ MPs were analyzed. We selected EMPs (CD31+, CD62E+) and platelet-derived $(\mathrm{CD} 61+, \mathrm{CD} 41+, \mathrm{CD} 42 \mathrm{a}+, \mathrm{PAC} 1+)$, red-blood-cell-derived (GlyA+) and leukocyte-derived (CD45+, CD13+, CD14+, CD 56+) MPs. The selected CD markers, their cellular origin, the fluorescent dye used for labeling and the manufacturer's specification for our MP measurements are summarized in Table 1. The individual antibody cocktail tubes are listed in Table $\mathrm{S} 1$. 
Table I CD markers used for MP measurements

\begin{tabular}{|c|c|c|c|c|}
\hline CD marker & Cellular origin & Function & Fluorescent dye & Manufacturer \\
\hline CD6I & Platelet & $\begin{array}{l}\text { Integrin } \beta 3 \text { chain with CD4I forms GPIIb/IIla, } \\
\text { receptor for fibrinogen, fibronectin, plasminogen, } \\
\text { prothrombin, vitronectin, thrombospondin; with } \\
\text { CD5I forms vitronectin receptor, role in cell } \\
\text { adhesion without activation }\end{array}$ & FITC & Beckman Coulter \\
\hline CD4I & Platelet & $\begin{array}{l}\text { Integrin } \alpha \text { IIB chain with CD6I forms GPIIb/llla } \\
\text { has a crucial role in coagulation }\end{array}$ & Сy5 & Becton Dickinson \\
\hline $\begin{array}{l}\text { CD42a } \\
(\mathrm{GPIb} / \mathrm{V} / \mathrm{IX})\end{array}$ & Platelet & $\begin{array}{l}\text { GPIX that forms receptor complex with GPIb } \\
\text { and GPV; von Willebrand factor and high-affinity } \\
\text { thrombin-binding site }\end{array}$ & FITC & Becton Dickinson \\
\hline $\begin{array}{l}\mathrm{PACl} \\
\text { (GPIIb/IIla) }\end{array}$ & $\begin{array}{l}\text { Platelet (activation } \\
\text { marker) }\end{array}$ & $\begin{array}{l}\text { Present only on the surface of activated } \\
\text { platelets, recognizes an epitope on the GPIIb/IIla } \\
\text { complex of activated platelets at or near the } \\
\text { platelet fibrinogen receptor }\end{array}$ & FITC & Becton Dickinson \\
\hline CD3I (PECAM-I) & Endothelial cell & $\begin{array}{l}\text { PECAM-I, major constituent of endothelial } \\
\text { intercellular junction, required for leukocyte } \\
\text { trans-endothelial migration under inflammatory } \\
\text { conditions }\end{array}$ & PE & Becton Dickinson \\
\hline $\begin{array}{l}\text { CD62E } \\
\text { (ELAM-I/E-selectin) }\end{array}$ & $\begin{array}{l}\text { Endothelial cell } \\
\text { (activation marker) }\end{array}$ & $\begin{array}{l}\text { ELAM-I, expressed on the surface of activated } \\
\text { endothelial cells, mainly in inflammation }\end{array}$ & $\mathrm{PE}$ & Becton Dickinson \\
\hline CD45 & Leukocyte & Pan leukocyte marker & FITC & Beckman Coulter \\
\hline $\begin{array}{l}\mathrm{CD} / 3 \\
\text { (aminopeptidase N) }\end{array}$ & Leukocyte & $\begin{array}{l}\text { Present on the surface of granulocytes } \\
\text { and monocytes }\end{array}$ & PE & Beckman Coulter \\
\hline CDI4 (LPS-R) & Monocyte & $\begin{array}{l}\text { LPS receptor, present on the surface } \\
\text { of monocytes/macrophages }\end{array}$ & $\mathrm{PE}$ & Beckman Coulter \\
\hline $\begin{array}{l}\text { CD235 } \\
\text { (glycophorin A) }\end{array}$ & Red blood cell & $\begin{array}{l}\text { Present on the surface of red blood cells } \\
\text { and their precursors }\end{array}$ & $\mathrm{PE}$ & Becton Dickinson \\
\hline CD56 (NCAM) & $\begin{array}{l}\text { NK cells, activated } \\
\text { CD8+ } T \text { cells }\end{array}$ & Role in cell-cell adhesion & Cy5 & Becton Dickinson \\
\hline Annexin V & $\begin{array}{l}\text { Recognizes } \\
\text { phosphatidylserine }\end{array}$ & $\begin{array}{l}\text { Present on the surface of activated } \\
\text { and apoptotic cells }\end{array}$ & FITC, Cy5 & Becton Dickinson \\
\hline Mouse $\lg G I$ & Isotype control & & FITC, PE, Cy5 & Becton Dickinson \\
\hline
\end{tabular}

Note: Cellular origin and function of $C D$ markers, fluorescent dye and the manufacturer's specification.

Abbreviations: Cy5, CyChrome (PE-Cy5 conjugate); ELAM-I, endothelial leukocyte adhesion molecule I; FITC, fluorescein isothiocyanate; Ig, immunoglobulin; LPS, lipopolysaccharide; LPS-R, lipopolysaccharide receptor; NCAM, neural cell adhesion molecule; PE, phycoerythrin; PECAM-I, platelet endothelial cell adhesion molecule.

For sample labeling, $10 \mu \mathrm{L}$ of MP suspension in $\mathrm{Ca}^{2+}-$ free buffer was incubated in $100 \mu \mathrm{L}$ Apo-binding buffer supplemented with $2.5 \mathrm{mmol} / \mathrm{L} \mathrm{CaCl}_{2}$ with total $10 \mu \mathrm{L}$ antibody, previously diluted to optimal labeling concentration. Staining was incubated for 30 minutes at room temperature in dark chamber. All buffers were filtered through $0.2 \mu \mathrm{m}$ membrane filters.

\section{Flow cytometric analysis}

The method described in International Society on Thrombosis and Hemostasis (ISTH) SSC standardization study with minor modifications was used for the flow cytometric MP analyses. ${ }^{11,12}$ Flow cytometric measurements and data analysis were performed on Beckman Coulter (Brea, CA, USA) FC-500 cytometer with CXP software. MP's reference gate was defined using $0.3 \mu \mathrm{m}, 0.5 \mu \mathrm{m}$ and $0.9 \mu \mathrm{m}$ FITC-labeled polystyrene microbeads (Soft Flow Ltd., Pécs, Hungary). Side scatter, forward scatter and fluorescence channels were set in logarithmic scale. MP size gate was determined between 0.5 and $1.0 \mu \mathrm{m}$ size range. Events in the MP gate were further discriminated by labeling with Annexin V. MPs were defined as Annexin V-positive events in the MP gate with fluorescence intensity above the isotype control.

For the determination of the MP number, known concentration $\left(1 \times 10^{5} / \mathrm{mL}\right)$ of $3 \mu \mathrm{m}$ diameter microbeads (BD Biosciences, Franklin Lakes, NJ, USA) was used (Figure 1). To determine the optimal labeling concentrations, all antibodies and Annexin V were titrated. Labeling concentrations were defined by antibody staining of samples and sample-free buffers in the presence or absence of $\mathrm{CaCl}_{2}$. Labeling was 


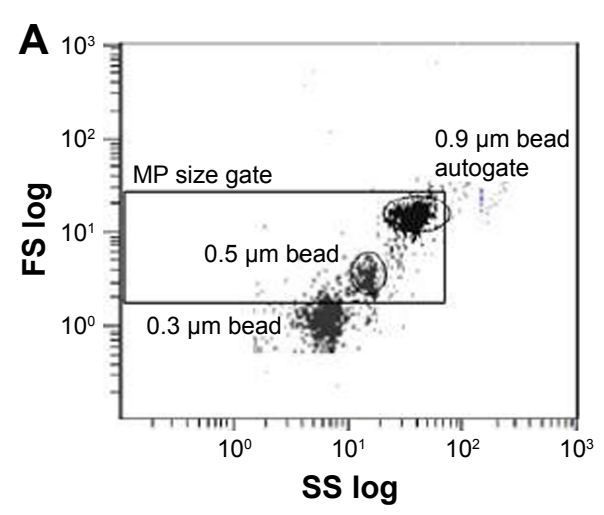

B

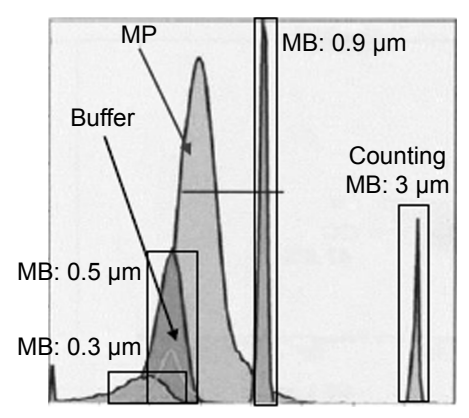

FS log
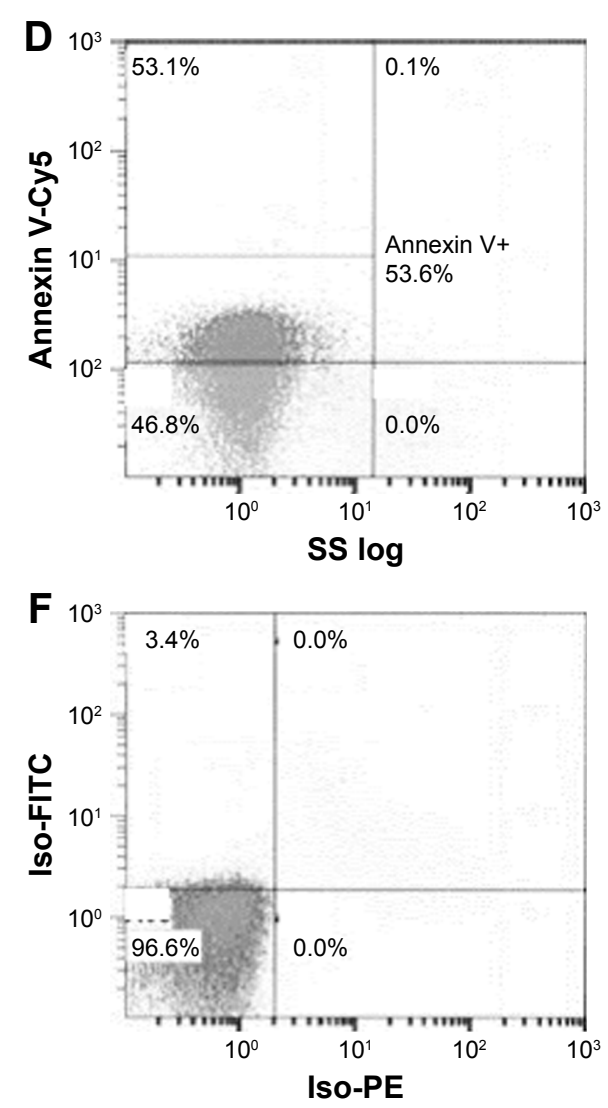
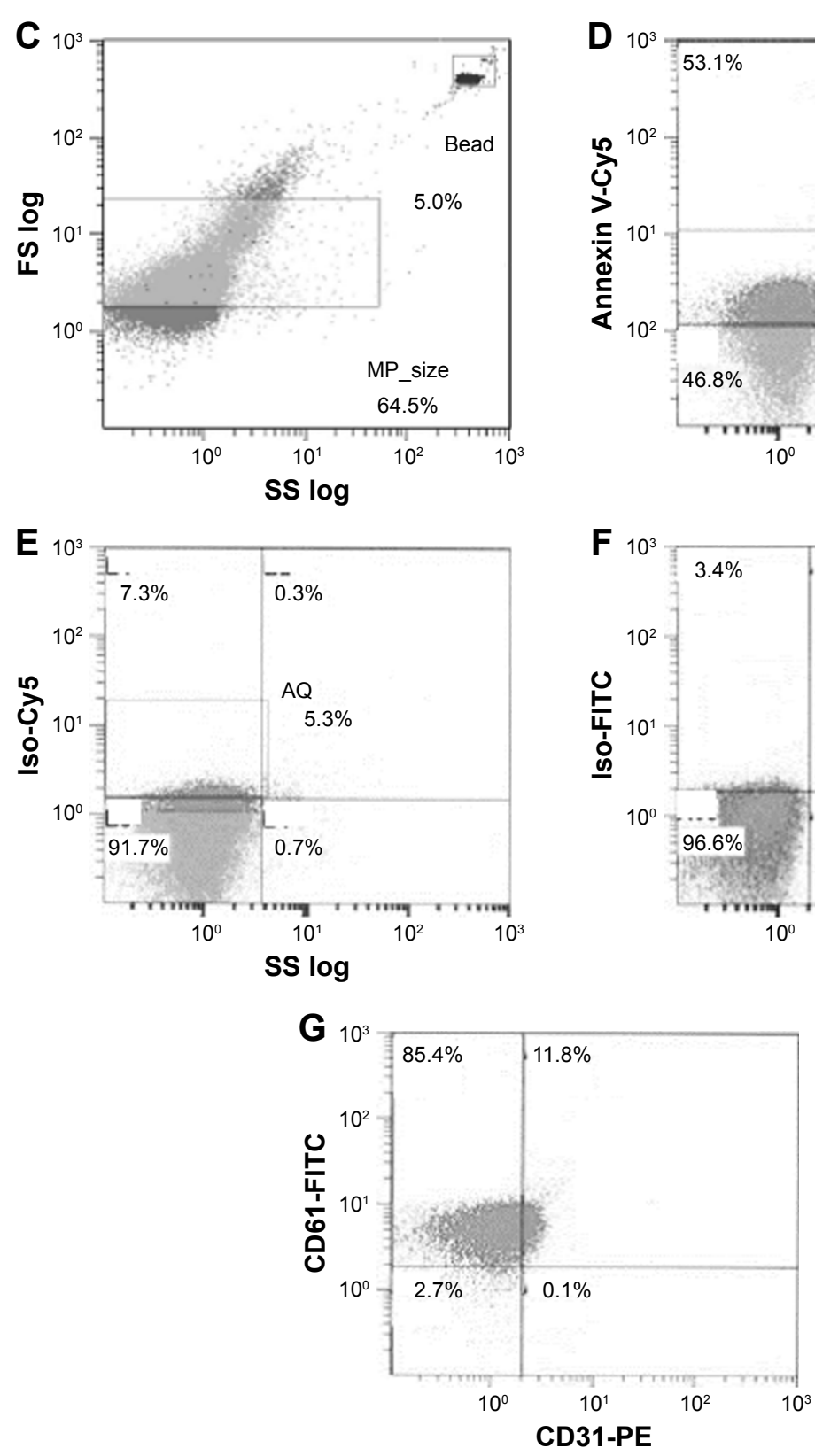

Figure I FC gating strategy used for MP measurement.

Notes: (A-C) MP size gate was determined using $0.3 \mu \mathrm{m}, 0.5 \mu \mathrm{m}$, and $0.9 \mu \mathrm{m}$ FITC-labeled polystyrene MBs. The lower side of the gate was set below $0.5 \mu \mathrm{m}$ bead as a threshold, because the $0.3 \mu \mathrm{m}$ and $0.5 \mu \mathrm{m}$ bead histogram displayed an overlap indicating that the cytometer would not be able to discriminate individual MPs between these size ranges. The upper side of the gate was set at the upper and right sides of the $0.9 \mu \mathrm{m}$ bead cloud. In this MP gate, the buffer and the sample containing MPs can be clearly distinguished. (D-G) MPs were defined as Annexin V+ events in the size gate, with fluorescence intensity above isotype control and the sample-free buffer.

Abbreviations: Cy5, CyChrome (PE-Cy5 conjugate); FC, flow cytometry; FITC, fluorescein isothiocyanate; FS, forward scatter; Iso, isotype; MB, microbeads; MP, microparticle; PE, phycoerythrin.; SS, side scatter. 
considered optimal if $\mathrm{CaCl}_{2}$-labeled sample measurement events were clearly distinguishable from background and $\mathrm{CaCl}_{2}$-free staining as well as from isotype controls.

As a positive control, we used MPs isolated from pooled platelet-rich plasma after stimulation with calcium ionophore A23186 (Sigma-Aldrich Co., $25 \mu \mathrm{mol} / \mathrm{mL}$ ). The pooled platelet-rich plasma was collected from healthy volunteers. Negative controls were MPs stained with Annexin V in the presence of $2.5 \mathrm{mmol} / \mathrm{L}$ EDTA.

\section{Statistical analyses}

Statistical analyses were done using SPSS 22 version for Windows (IBM Corporation, Armonk, NY, USA). For investigating differences between patient groups, MannWhitney $U$ test and Kruskal-Wallis test were used because of non-normal distribution of values. Chi-squared test was used to compare categorical variables. Correlation analysis was carried out using Spearman's test. Data are presented as median (IQR). In calculations, $P<0.05$ was considered to be statistically significant.

\section{Results}

Demographic and clinical data of COPD patients are summarized in Table 2 . A total of 19 healthy subjects served as controls (nine males and 10 females) with the median age of 57 (49-63) years. The number of smokers was $8(42 \%)$.

\section{MPs in control subjects vs stable COPD patients}

All the measured MPs such as CD31+ and CD62E+ with endothelial; CD61+, CD41+, CD42a+ and PAC1+ with platelet; GlyA+ with red blood cell, CD45+ and CD13+ with leukocyte; CD14+ with monocyte and CD56+ with lymphocyte origin showed significant $(P<0.001)$ elevation in stable COPD patients compared to controls (Table 3 ).

Table 2 Demographic and clinical data of COPD patients

\begin{tabular}{|c|c|c|c|}
\hline & Stable COPD $(n=34)$ & AECOPD $(n=16)$ & $P$-value \\
\hline Age (years) ${ }^{a}$ & $63(54-70)$ & $63(56-67)$ & 0.755 \\
\hline Male $^{\mathrm{b}}$ & $20(59)$ & $9(56)$ & 0.863 \\
\hline \multicolumn{4}{|l|}{ Chronic diseases } \\
\hline $\mathrm{DM}^{\mathrm{b}}$ & $2(6)$ & $5(31)$ & 0.03 \\
\hline $\mathrm{CVD}^{\mathrm{b}}$ & $20(58)$ & $9(56)$ & 0.863 \\
\hline Smoking ${ }^{\mathrm{b}}$ & $20(59)$ & $10(62)$ & 0.804 \\
\hline \multicolumn{4}{|l|}{ Medication } \\
\hline Ca channel blockers ${ }^{\mathrm{b}}$ & $8(23)$ & $10(62)$ & 0.009 \\
\hline$\beta$-blockers ${ }^{\mathrm{b}}$ & $17(50)$ & $7(44)$ & 0.680 \\
\hline $\mathrm{ACEl}^{\mathrm{b}}$ & $13(38)$ & $6(37)$ & 0.898 \\
\hline Statin $^{\mathrm{b}}$ & $2(6)$ & $3(19)$ & 0.320 \\
\hline$I C S^{b}$ & $25(74)$ & $14(87)$ & 0.464 \\
\hline $\mathrm{LABA}^{\mathrm{b}}$ & $26(77)$ & $14(87)$ & 0.698 \\
\hline LAMA $^{\mathrm{b}}$ & $32(94)$ & $14(87)$ & 0.245 \\
\hline \multicolumn{4}{|l|}{ Lung function } \\
\hline $\mathrm{FEV}_{1} / \mathrm{FVC}^{\mathrm{a}}$ & $0.56(0.4 I-0.63)$ & $0.49(0.37-0.55)$ & 0.179 \\
\hline FEV, ref $\%^{\mathrm{a}}$ & $0.52(0.36-0.67)$ & $0.56(0.45-0.67)$ & 0.925 \\
\hline \multicolumn{4}{|l|}{ GOLD stage } \\
\hline GOLD I-IIb & $21(62)$ & $10(62)$ & 0.96 \\
\hline GOLD III-IVb & $13(32)$ & $6(37)$ & 0.96 \\
\hline \multicolumn{4}{|l|}{ Routine parameters } \\
\hline Cholesterola $^{\mathrm{a}}(\mathrm{mmol} / \mathrm{L})$ & $5.50(5.00-6.80)$ & $4.95(4.10-6.10)$ & 0.151 \\
\hline RBC count ${ }^{\mathrm{a}}(\mathrm{T} / \mathrm{L})$ & $4.89(4.43-5.22)$ & $4.99(4.49-5.29)$ & 0.677 \\
\hline PLT count ${ }^{\mathrm{a}}(\mathrm{G} / \mathrm{L})$ & $232(172-276)$ & $267(195-328)$ & 0.112 \\
\hline WBC count $^{\mathrm{a}}(\mathrm{G} / \mathrm{L})$ & $7.55(5.76-9.76)$ & I3.53 (8.99-I5.85) & $<0.001$ \\
\hline hs-CRPa (mg/L) & $5.65(3.50-8.30)$ & $9.67(2.93-23.61)$ & 0.114 \\
\hline
\end{tabular}

Notes: Median $(\mathrm{IQR})^{\mathrm{a}}$ and $\mathrm{n}(\%)^{\mathrm{b}}$ are presented. Mann-Whitney $\mathrm{U}$ test and chi-squared test were used to compare variables.

Abbreviations: ACEl, angiotensin-converting enzyme inhibitor; AECOPD, acute exacerbation of COPD; CVD, cardiovascular disease; DM, diabetes mellitus; G, giga; hs-CRP, high-sensitivity C-reactive protein; ICS, inhaled corticosteroid; LABA, long-acting $\beta$-agonist; LAMA, long-acting muscarinic antagonist; PLT, platelet; RBC, red blood cell; T, tera; WBC, white blood cell. 
Table 3 Number of MPs in control subjects and patients with stable and AECOPD

\begin{tabular}{|c|c|c|c|c|c|}
\hline $\begin{array}{l}\text { CD markers } \\
\left(\times 10^{5} / \mathrm{mL}\right)\end{array}$ & $\begin{array}{l}\text { Control } \\
\text { group }(n=19)\end{array}$ & $\begin{array}{l}\text { Stable COPD } \\
(n=34)\end{array}$ & $\begin{array}{l}\text { AECOPD } \\
(n=16)\end{array}$ & $\begin{array}{l}\text { P-value; control vs } \\
\text { stable and control vs } \\
\text { AECOPD }\end{array}$ & $\begin{array}{l}\text { P-value; stable } \\
\text { vs AECOPD }\end{array}$ \\
\hline Annexin V+ & $2.18(1.33-3.70)$ & $53.74(35.08-76.38)$ & 61.15 (44.26-73.39) & $<0.001$ & 0.747 \\
\hline CD3I+ & $0.79(0.48-1.40)$ & $10.35(7.78-17.04)$ & $15.59(11.82-21.95)$ & $<0.001$ & 0.164 \\
\hline CD62E+ & $1.72(0.97-3.17)$ & $29.87(26.85-40.58)$ & $44.09(33.43-59.21)$ & $<0.001$ & 0.011 \\
\hline CD6I+ & $2.10(1.22-3.65)$ & $48.36(32.02-73.68)$ & $54.99(38.18-65.73)$ & $<0.001$ & 0.992 \\
\hline CD4I+ & $1.51(0.90-2.46)$ & $37.99(32.69-52.59)$ & 61.15 (44.25-73.39) & $<0.001$ & 0.018 \\
\hline CD42a+ & $0.17(0.12-0.30)$ & $\mathrm{I} .32(0.92-\mathrm{I} .5 \mathrm{I})$ & $3.19(1.49-5.69)$ & $<0.001$ & 0.002 \\
\hline $\mathrm{PACl}+$ & $0.15(0.09-0.23)$ & $0.57(0.28-3.05)$ & $0.52(0.15-0.76)$ & $<0.001$ & 0.182 \\
\hline GlyA+ & $0.28(0.16-0.59)$ & $8.21(6.76-11.59)$ & $11.93(5.03-18.98)$ & $<0.001$ & 0.133 \\
\hline CD45+ & $1.88(1.10-2.94)$ & $37.67(26.34-59.24)$ & $43.21(20.29-60.07)$ & $<0.001$ & 0.670 \\
\hline CDI3+ & $1.62(0.99-3.19)$ & $30.37(21.32-5,500)$ & $41.44(26.9 I-46.07)$ & $<0.001$ & 0.904 \\
\hline CDI4+ & $0.07(0.06-0.11)$ & $0.29(0.08-0.48)$ & $0.624(0.44-0.98)$ & $<0.001$ & 0.008 \\
\hline CD56+ & $1.02(0.63-1.88)$ & $43.99(32.8 \mathrm{I}-54.94)$ & $61.15(42.02-73.40)$ & $<0.001$ & 0.240 \\
\hline
\end{tabular}

Notes: Median (IQR) data are presented. Kruskal-Wallis test was used to compare variables.

Abbreviations: AECOPD, acute exacerbation of COPD; MPs, microparticles.

\section{MPs in stable vs acute exacerbation of COPD (AECOPD) patients}

Importantly, we detected statistically significant differences in patients with AECOPD vs stable COPD patients: the number of CD62E+, CD41+, CD42a+ and CD14+ MPs was significantly $(P<0.05)$ higher in the AECOPD group (Table 3). These endothelial-, platelet- and monocyte-derived MP numbers showed a remarkable elevation in acute exacerbation state of COPD patients.

After dichotomizing patients based on GOLD stages, an increased number $(P=0.031)$ of PAC $1+$ MPs were observed in severe cases indicated by GOLD III and IV (Figure 2).

In addition, multivariate analyses showed that CD62E+, $\mathrm{CD} 42 \mathrm{a}+$ and $\mathrm{CD} 14+\mathrm{MPs}$ correlate inversely with $\mathrm{FEV}_{1} / \mathrm{FVC}$ $(-0.406,-0.473,-0.440, P<0.001$, respectively).

\section{Discussion}

There is a growing evidence of applying MP analysis in the diagnostic process. However, the heterogeneity of the area makes it difficult to use MPs as potential biomarkers. A wide variety of sample preparation processes, in-house developments, different gating and measurement methods, diversity of the tested $\mathrm{CD}$ markers and small number of controls makes it almost impossible to compare the results of the research groups. There are no standard methods (solid phase capture techniques, electron microscopy, atomic force microscopy, transmission electron microscopy, nanoparticle tracking analysis and flow cytometry analysis) and standard protocols (different centrifugation time, cycles and forces, different sample types) for MP measurements. ${ }^{13-17}$
Besides, there is no consensus on the use of MP-labeling antibodies. Different fluorochrome-labeled antibodies recognize different $\mathrm{CD}$ markers on the cell surface; however, these CD markers are represented in different densities. Consequently, the amounts of MPs can vary in wide ranges making results difficult to compare. It is also challenging to differentiate MPs from exosomes (30-100 nm) or apoptotic bodies $(1-4 \mu \mathrm{m})$ during the workflow and analysis.

During our study, we successfully introduced a reliable flow cytometric method on Beckman Coulter FC500 flow cytometer for the measurement of MPs. Certainly, our

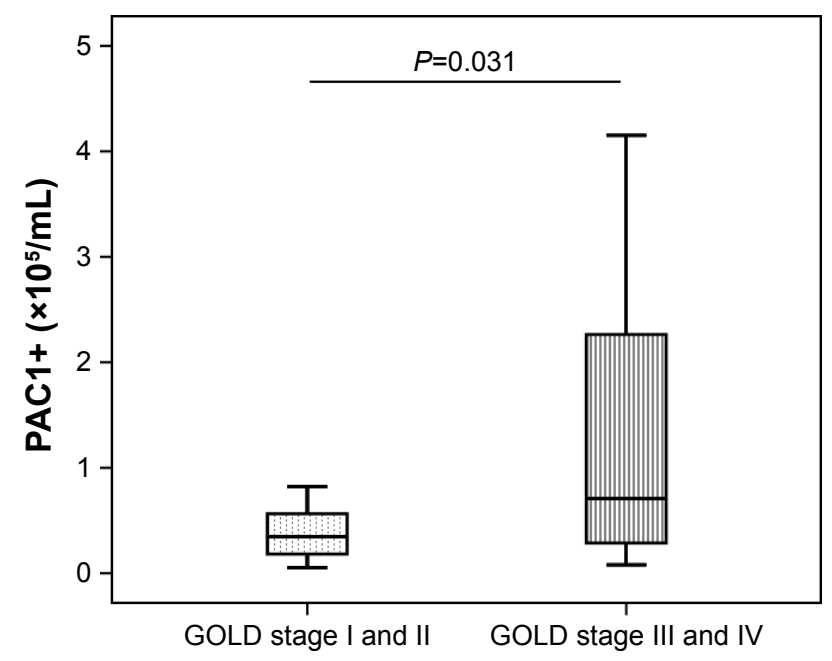

Figure 2 Comparison of PACI+ MPs in patients with GOLD stage I-II vs stage III-IV.

Note: $\mathrm{PACl}+\mathrm{MP}$ numbers are significantly increased in patients with GOLD stage III-IV compared to patients with GOLD stage I-II (data are presented as median and 25-75th percentiles, Mann-Whitney test, $P=0.031$ ).

Abbreviation: MPs, microparticles. 
method has also some limitations. Besides the advantages of the method such as small sample size, relative wide availability and the capability to measure in parallel the number and the cellular origin of the MPs, the main disadvantage is the low size sensitivity. The FS (forward scatter) detector detects scattered light at an angle of $1^{\circ}-70^{\circ}$ depending on the setup of the instrument. ${ }^{18} \mathrm{~A}$ higher collection angle reflects higher sensitivity. ${ }^{19}$ Most of the commercially available cytometers have an FS size limit around $0.5 \mu \mathrm{m}$ due to the laser light wavelength ( $488 \mathrm{~nm}$ ), restricting the accurate measurement of MPs in the lower size range. Consequently, only a fraction of MPs above this size can be detected with old type of cytometers. ${ }^{11,20}$ This limits the assessment of whole MP population taking into account that the MP size range is between 0.1 and $1.0 \mu \mathrm{m}$. New flow cytometers such as the Beckman Coulter (Brea, CA, USA) Gallios ${ }^{\mathrm{TM}}$, BD (Becton Dickinson, San Jose, CA, USA) FACSAria ${ }^{\mathrm{TM}}$ III, Apogee (Apogee Flow Systems Ltd, Northwood, England) A40/A50 are promising for the measurement of MP populations with lower size, because they have been designed to address this issue by increasing the FS collection angle. ${ }^{20-22}$

The amount of studied MPs in our control group is in agreement with previous studies; however, due to technical variety, there is no international reference range for MP level. ${ }^{11,21,23}$ Moreover, some research groups use only platelet poor plasma (PPP), while others also pellet the MPs before labeling. Both PPP and PFP contain some residual platelet contamination, and thus this fact may affect the final MP count. Our protocol is capable of identifying only MPs without residual contamination and it is ideal for clinical investigations. Studies that present results about MPs in a certain patient population, such as COPD, provide useful information about their predictive value as a biomarker.

Studies to date have been focused only on EMPs in COPD; however, MPs from other origins may also play a pivotal role in COPD. ${ }^{24-26}$ It is known that MPs originating from platelets and monocytes may play an important role in the development and progression of COPD. ${ }^{27}$ However, very limited data are available so far. To the best of our knowledge, this is the first study which investigates various MPs in COPD. In our study besides EMPs (CD31+, CD62E+), we analyzed the platelet-originating (CD61+, CD41+, CD42a+, $\mathrm{PAC} 1+)$, red blood cell-originating (GlyA+) and leukocyteoriginating (CD45+, CD13+, CD14+, CD56+) MP populations as well. Despite the relatively low number of cases, we found significant differences between COPD and the control group. Highly elevated MP levels can be interpreted as cell activation, tissue damage, inflammation and apoptosis which are known to be pathophysiologic processes in COPD. ${ }^{28}$
Recently, EMPs have been described as possible pathogenic factors and prognostic markers of COPD and emphysema. ${ }^{25,26}$ We also found elevated CD62E+ MP values; moreover, exacerbated COPD patients showed higher levels than stable COPD. This finding is consistent with the observations of Takahashi et $\mathrm{al}^{24}$ and could be explained by endothelial activation and vascular injury in the lungs during COPD.

A novel observation of our study that not only EMPs are elevated in exacerbated COPD but also platelet-derived CD41+ and CD42a+ and monocyte-derived CD14+ MPs also take a significant part in COPD exacerbations.

An inverse correlation with lung functions and the elevation in exacerbated cases could make them a candidate as potential predictive biomarker and confirm their role in COPD pathophysiology.

The causative role of such specific MPs in the pathophysiology of exacerbations still should be elucidated. In addition, these thrombo-inflammatory pathway-related MPs may also regulate the airway functions, because an inverse correlation was found between them and the lung function $\left(\mathrm{FEV}_{1} / \mathrm{FVC}\right)$. In accordance with our findings, a negative correlation between endothelium-derived CD31+ MPs and $\mathrm{FEV}_{1} / \mathrm{FVC}$ was recently observed in the sputum of COPD patients. ${ }^{29}$ Although, MPs from the sputum were not investigated in our study, parallel measurement of MPs especially their kinetics in both the airway and the systemic circulation would clinically be worthwhile and elevations in exacerbated cases could make them candidates as potential predictive biomarkers.

Probably due to the low number of patients, we could not detect significant differences regarding smoking habits, medications and comorbidities. However, as it is suggested by other authors, these factors might increase MP values..$^{26,30}$ COPD is also associated with several comorbidities, probably linked together through the systemic inflammation. ${ }^{7,8}$ Similarly, high levels of MPs with different cellular origins (platelet, leukocyte, endothelial) were described in CVD patients that may play different roles in cross talk between endothelial and other cell types and should be the potential effectors in inflammation and vascular injury. ${ }^{30}$

\section{Limitations of the study}

Besides the relatively low number of cases, there are several limitations in our study: 1) in contrast to other sources of MPs, such as the sputum, blood cell-derived MPs were examined only in the systemic circulation here; 2) instead of single measurement, the kinetics of the MPs would be more informative; 3) MPs derived from airway epithelium were not investigated in our cohort. 


\section{Conclusion}

This study presented a reliable method for MP analysis. Elevated MP values in exacerbated COPD patients may help to recognize disease progression and to start adequate therapy to achieve a better clinical outcome. However, to apply MPs as potential predictive biomarkers of COPD worsening and outcome, further studies are needed.

\section{Acknowledgment}

The experiments were supported by NKFI-EPR 115394 , EFOP-3.6.2-16-2017-00009, EFOP-3.6.1.-16-2016- 00004 Comprehensive Development for Implementing Smart Specialization Strategies and EFOP-3.6.3-VEKOP-16-201700009 at the University of Pécs

\section{Author contributions}

All authors contributed toward data analysis, drafting and revising the paper, gave approval of the final version to be published and agree to be accountable for all aspects of the work.

\section{Disclosure}

The authors report no conflicts of interest in this work.

\section{References}

1. Hugel B, Martínez MC, Kunzelmann C, Freyssinet JM. Membrane microparticles: two sides of the coin. Physiology. 2005;20:22-27.

2. Ullal AJ, Pisetsky DS, Reich CF. Use of SYTO 13, a fluorescent dye binding nucleic acids, for the detection of microparticles in in vitro systems. Cytometry A. 2010;77(3):NA-301.

3. Vanwijk MJ, Vanbavel E, Sturk A, Nieuwland R. Microparticles in cardiovascular diseases. Cardiovasc Res. 2003;59(2):277-287.

4. Cocucci E, Racchetti G, Meldolesi J. Shedding microvesicles: artefacts no more. Trends Cell Biol. 2009;19(2):43-51.

5. Piccin A, Murphy WG, Smith OP. Circulating microparticles: pathophysiology and clinical implications. Blood Rev. 2007;21(3):157-171.

6. Takahashi T, Kubo H. The role of microparticles in chronic obstructive pulmonary disease. Int J Chron Obstruct Pulmon Dis. 2014;9: 303-314.

7. Agustí A, Faner R. Systemic inflammation and comorbidities in chronic obstructive pulmonary disease. Proc Am Thorac Soc. 2012;9(2):43-46.

8. Divo M, Cote C, de Torres JP, et al. Comorbidities and risk of mortality in patients with chronic obstructive pulmonary disease. Am J Respir Crit Care Med. 2012;186(2):155-161.

9. Global Strategy for the Diagnosis, Management and Prevention of COPD, Global Initiative for Chronic Obstructive Lung Disease (GOLD) 2017. Available from: https://goldcopd.org. Accessed october 13, 2018.

10. Taylor FB, Toh CH, Hoots WK, Wada H, Levi M. Scientific Subcommittee on Disseminated Intravascular Coagulation (DIC) of the International Society on Thrombosis and Haemostasis (ISTH). Towards definition, clinical and laboratory criteria, and a scoring system for disseminated intravascular coagulation. Thromb Haemost. 2001;86(5):1327-1330.
11. Robert S, Poncelet P, Lacroix R, et al. Standardization of plateletderived microparticle counting using calibrated beads and a Cytomics FC500 routine flow cytometer: a first step towards multicenter studies? J Thromb Haemost. 2009;7(1):190-197.

12. Lacroix R, Robert S, Poncelet $P$, et al. Standardization of platelet-derived microparticle enumeration by flow cytometry with calibrated beads: results of the International Society on Thrombosis and Haemostasis SSC Collaborative workshop. J Thromb Haemost. 2010;8(11):2571-2574.

13. Jy W, Horstman LL, Jimenez JJ, et al. Measuring circulating cell-derived microparticles. J Thromb Haemost. 2004;2(10):1842-1843.

14. van der Pol E, Hoekstra AG, Sturk A, Otto C, van Leeuwen TG, Nieuwland R. Optical and non-optical methods for detection and characterization of microparticles and exosomes. J Thromb Haemost. 2010;8(12):2596-2607.

15. Yuana Y, Oosterkamp TH, Bahatyrova S, et al. Atomic force microscopy: a novel approach to the detection of nanosized blood microparticles. J Thromb Haemost. 2010;8(2):315-323.

16. Dragovic RA, Gardiner C, Brooks AS, et al. Sizing and phenotyping of cellular vesicles using Nanoparticle Tracking Analysis. Nanomedicine. 2011;7(6):780-788.

17. Shet AS. Characterizing blood microparticles: technical aspects and challenges. Vasc Health Risk Manag. 2008;4(4):769-774.

18. Picot J, Guerin CL, Le van Kim C, Boulanger CM. Flow cytometry: retrospective, fundamentals and recent instrumentation. Cytotechnology. 2012;64(2):109-130.

19. van der Pol E, van Gemert MJ, Sturk A, Nieuwland R, van Leeuwen TG. Single vs. swarm detection of microparticles and exosomes by flow cytometry. J Thromb Haemost. 2012;10(5):919-930.

20. Chandler WL, Yeung W, Tait JF. A new microparticle size calibration standard for use in measuring smaller microparticles using a new flow cytometer. J Thromb Haemost. 2011;9(6):1216-1224.

21. Nielsen MH, Beck-Nielsen H, Andersen MN, Handberg A. A flow cytometric method for characterization of circulating cell-derived microparticles in plasma. J Extracell Vesicles. 2014;3(1):20795.

22. Poncelet P, Robert S, Bouriche T, Bez J, Lacroix R, Dignat George F. Standardized counting of circulating platelet microparticles using currently available flow cytometers and scatter-based triggering: Forward or side scatter? Cytometry Part A. 2016;89(2):148-158.

23. Gustafson CM, Shepherd AJ, Miller VM, Jayachandran M. Age- and sex-specific differences in blood-borne microvesicles from apparently healthy humans. Biol Sex Differ. 2015;6:10

24. Takahashi $\mathrm{T}$, Kobayashi S, Fujino N, et al. Increased circulating endothelial microparticles in COPD patients: a potential biomarker for COPD exacerbation susceptibility. Thorax. 2012;67(12):1067-1074.

25. Thomashow MA, Shimbo D, Parikh MA, et al. Endothelial microparticles in mild chronic obstructive pulmonary disease and emphysema. The Multi-Ethnic Study of Atherosclerosis Chronic Obstructive Pulmonary Disease study. Am J Respir Crit Care Med. 2013;188(1):60-68.

26. Gordon C, Gudi K, Krause A, et al. Circulating endothelial microparticles as a measure of early lung destruction in cigarette smokers. $\mathrm{Am}$ $J$ Respir Crit Care Med. 2011;184(2):224-232.

27. Kadota T, Fujita Y, Yoshioka Y, Araya J, Kuwano K, Ochiya T. Extracellular Vesicles in Chronic Obstructive Pulmonary Disease. Int J Mol Sci. 2016;17(11):1801.

28. Nieri D, Neri T, Petrini S, Vagaggini B, Paggiaro P, Celi A. Cell-derived microparticles and the lung. Eur Respir Rev. 2016;25(141):266-277.

29. Lacedonia D, Carpagnano GE, Trotta T, et al. Microparticles in sputum of COPD patients: a potential biomarker of the disease? Int J Chron Obstruct Pulmon Dis. 2016;11:527-533.

30. Tomaniak M, Gąsecka A, Filipiak KJ. Cell-derived microvesicles in cardiovascular diseases and antiplatelet therapy monitoring - A lesson for future trials? Current evidence, recent progresses and perspectives of clinical application. Int J Cardiol. 2017;226:93-102. 


\section{Supplementary material}

Table SI Individual antibody cocktails used for MP measurements

\begin{tabular}{|l|l|l|l|}
\hline Tube & FITC-labeled CD markers & PE-labeled CD markers & Cy5-labeled CD markers \\
\hline Tube I & CD6I FITC & CD3I PE & Annexin V Cy5 \\
\hline Tube 2 & Annexin V FITC & CDI3 PE & CD4I Cy5 \\
\hline Tube 3 & PACI FITC & CDI4 PE & Annexin V Cy5 \\
\hline Tube 4 & Annexin V FITC & GlyA PE & CD56 Cy5 \\
\hline Tube 5 & CD42a FITC & CD62E PE & Annexin V Cy5 \\
\hline Tube 6 & CD45 FITC & - & Annexin V Cy5 \\
\hline Tube 7 & Iso FITC & Iso PE & Iso Cy5 \\
\hline
\end{tabular}

Abbreviations: $\mathrm{Cy} 5$, CyChrome (PE-Cy5 conjugate); FITC, fluorescein isothiocyanate; MP, microparticle; PE, phycoerythrin.

\section{Publish your work in this journal}

The International Journal of COPD is an international, peer-reviewed journal of therapeutics and pharmacology focusing on concise rapid reporting of clinical studies and reviews in COPD. Special focus is given to the pathophysiological processes underlying the disease, intervention programs, patient focused education, and self management protocols.

\section{Dovepress}

This journal is indexed on PubMed Central, MedLine and CAS. The manuscript management system is completely online and includes a very quick and fair peer-review system, which is all easy to use. Visit http://www.dovepress.com/testimonials.php to read real quotes from published authors. 